\title{
The Impact of Megatrends on Marketing Communications Education. Results of an International Survey Among Educators
}

\author{
Dr. Gábor REKETTYE Jr., PhD \\ International Business School, Budapest, Hungary \\ E-mail: grekettye@ibs-b.hu
}

Dr. habil. Árpád PAPP-VÁRY, PhD

Metropolitan University, Budapest, Hungary

E-mail: apappvary@metropolitan.hu

\begin{abstract}
This paper examines the global megatrends affecting business practices and marketing and marketing communications education using the results of an international survey carried out by the authors to understand the effects of global megatrends, which included businesspeople as well as academics. For the research, the survey focuses only on academics and educators. The comparison of results includes advanced, developing and transition countries. The international nature of the study allowed a further comparison of expert opinions. The high share of educators in the sample allowed the researchers to make three predictions on requested changes in business and marketing education. The projections formulated in the study highlight the most significant changes: digital revolution or the advance of technology, the changing nature of marketing communications indicating the need for integration and emphasizing the importance of online communication, and finally the cultural sensitivity graduates must possess as a result of the changes taking place in higher education institutions.
\end{abstract}

Keywords: Marketing; Marketing communication; Megatrends; Marketing education; International research. 


\section{Introduction}

The practice of marketing, and especially marketing communication is perhaps the fastest-changing area of companies' operation and has never experienced a period in its brief past that was as difficult as the one it is facing now, and especially in the near future. The growth of the population, as well as the facets of globalization and other worldwide tendencies, are mostly reworking the day-to-day routine of marketing (Papp-Váry, 2013; Egan, 2015; Kotler et al., 2010; Quelch \& Jocz, 2009; Vijay, 2009; Wine, 2009). The authors of this study conducted comprehensive research based on a questionnaire survey involving business leaders and business educators from Croatia, India, Hungary and advanced countries including Australia, Austria, Canada, Finland, Denmark, Greece, Japan, Norway, Sweden, United Kingdom and the United States of America.

\section{Research Problem}

The aim of the research was twofold. Firstly, to explore how these opinion leaders felt about the effect of the megatrends on the future changes of the business environment in their respective countries. Secondly, to understand what changes in the marketing practice they expect due to the changing environment.

While processing the 315 questionnaires, it turned out that there were 157 business educators and academics among the respondents. It made it possible for the researchers to coin the third aim. From the answers of the educators, the research could predict the changes in business and marketing education that are needed for the modernization of marketing communications education and provide future graduates with knowledge and skills to be able to cope with the requirements of the expected new business environment and business practice.

\section{Research Model}

To meet the above requirements the research was based on the following research model (Figure 1).

The novelty of the paper is its predictions regarding the necessary changes in the business and marketing education based on the international sample's insights about the effects of the megatrends on the marketing practices. Education plays a pioneering role, transforming this new understanding into the curriculum of the business and marketing courses will help the future graduates tackle the possible challenges facing businesses as a result of these global megatrends. The findings of this paper present future possibilities of research to better understand how higher education needs to incorporate the newest trends in marketing and marketing communications into their curriculum. 


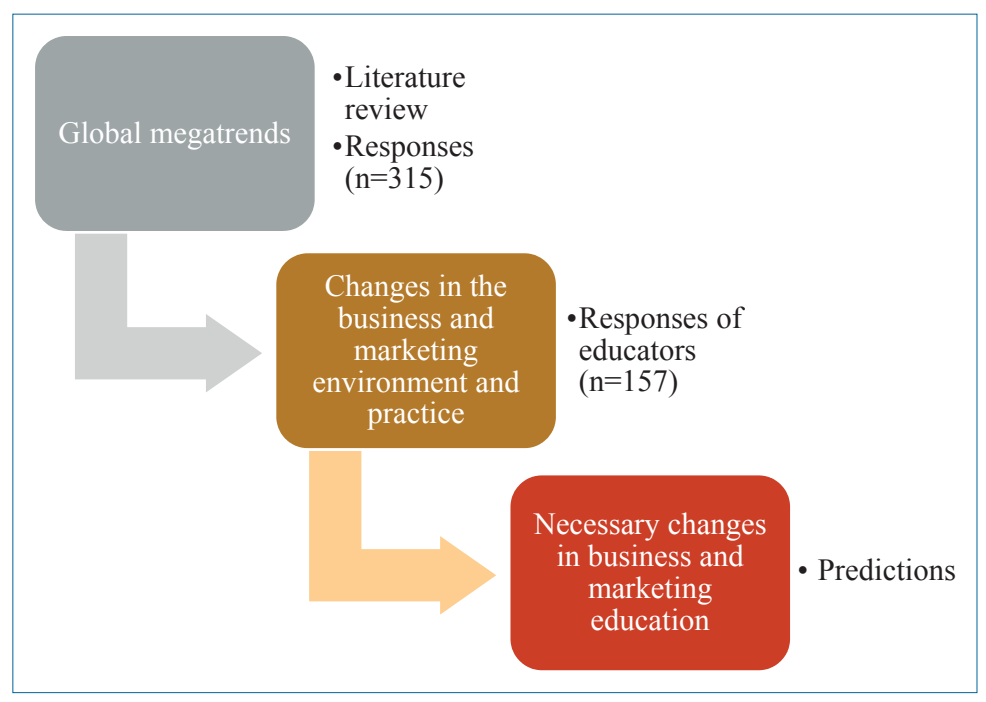

Figure 1. The model of the research

\section{Literature review}

\section{Global megatrends}

A comprehensive review of the literature helped to identify the global trends that will determine the future business and marketing environment. In the first phase of this secondary analysis (desk research) the forecasts of researchers and the predictions of renowned institutes and consulting companies were studied (Larsen 2006; NIC, 2012; Gregosz, 2012; Rekettye \& Rekettye Jr., 2013, Sell \& Vielmetter, 2014; Dobbs et al., 2015; Hajkowitcz, 2015). At the end of this phase, the study agreed with the forecast of Rekettye and Rekettye Jr. that six major megatrends will have a determining influence on the development of the global business scene in the future. These are as followings:

- An ever-accelerating transfer of power in the international economy, i.e. the economic power moving from the Western world to the East and to the South with a growing rate.

- The global climate change (global warming) threatening an ever-increasing number of countries and an ever-growing part of the inhabited world.

- Demographic changes, including three phenomena:

- The ageing population in Western societies

- Overpopulation and urbanization in third world countries, and

- The growing role of women in the economy

- The aftereffects of the global recession which are manifested in the lasting changes of consumer behavior. 
- The trend towards proliferation expressed in the clutter of new brands and communication tools.

- The increasing rate of technological development, especially in the IT and communication technology industry (digitalization).

All of the above trends are interconnected, and it is difficult to discuss them separately. Digging deeply into the literature it became evident that one of the tendencies will have an enormous effect on the others and the future development of the business environment: it is technological development, that is, digitalization (Porter \& Heppelmann, 2014; Monostori, 2015; Tao et al. 2015; Strange \& Zuchella, 2017). This trend is so strong that references to a fourth industrial revolution have already appeared. The compound 'fourth industrial revolution' is actually the title of a book written in 2016 by Klaus Schwab, founding member and current executive chairman of the World Economic Forum (Schwab, 2016). In his view, the world has now entered a stage of technological development that can be called a revolution. The change (development) which might overwrite previous trends, determine our whole life, and as such, can have a fundamental influence on the production of customer value, its motivating factors, methods of implementation, results and consequences. The emerging cyber-physical system will combine communication, information technology, data, physical elements, a host of basic technologies, receptors, the infrastructure of communication via the internet, intelligent and simultaneous processing, the participants of mechanical activities, 'big data' and the way it can be obtained, automated operation and management systems, advanced robotics, 3D and $4 \mathrm{D}$ printing. The possible results of this digital revolution are discussed in the literature mainly from the manufacturing side (Baur \& Wee, 2015; Rüßman et al., 2015; Geissbauer et al., 2016). However, the paradigm shift in production will also require radical changes in marketing and all other functions of business life.

Before going into details of the field research, it is worth looking into how educators of the countries involved in the study think about these megatrends (Figure 2).

The data in Figure 2 justify the conclusions of the literature review: educators rank digital development first. It is followed by the effect of climate change, demographic changes and the aftereffects of the recession. It leads us to formulate our first prediction concerning the possible directions of business education:

\section{Prediction no. 1}

The effects of the digital revolution should be given more emphasis in all areas of business education (business models, strategy, operations, marketing, human resource management, pricing, etc.). 


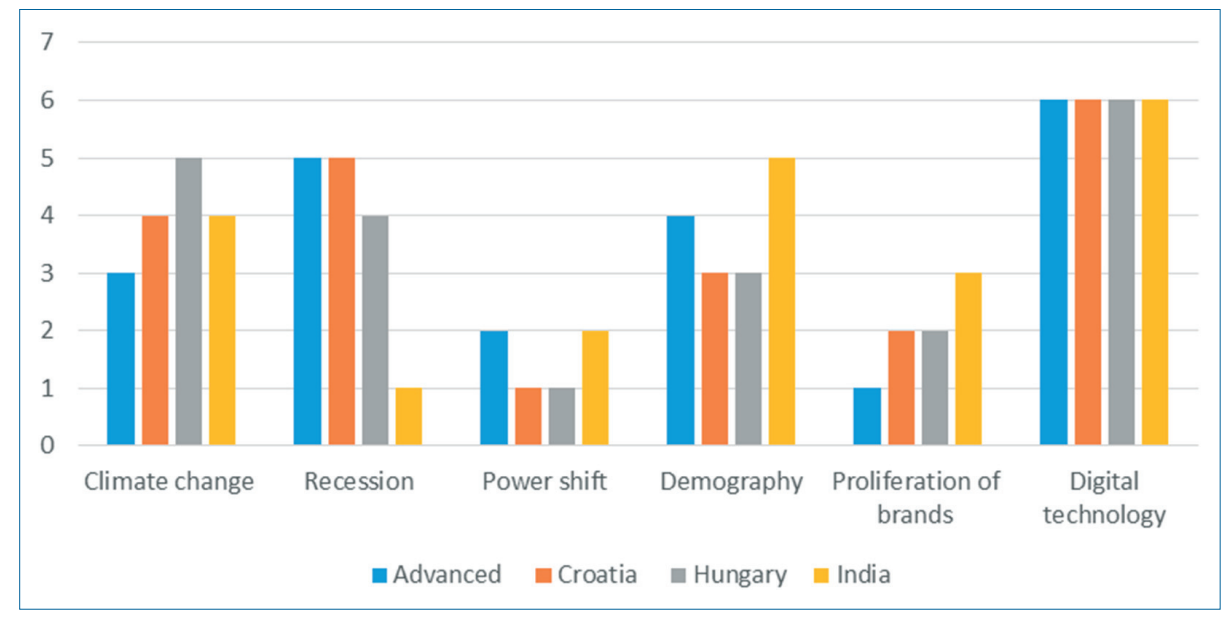

(6 = most important, $1=$ least important $) \mathrm{n}=157$

Figure 2. The ranking of megatrends according to the educators' responses Source: Own data

\section{Research Methodology}

\section{General Background}

The primary research aimed to provide an understanding of how the educators, marketing professors and other higher education professionals of the selected countries felt about the importance and influence of the identified megatrends. The other aim was to enable a complete comprehension of how forthcoming changes will affect the field of business and marketing, thus allowing the professionals to make predictions about the perspective of future curriculums, course designs and teaching materials related to marketing communications.

\section{The sample}

The primary research tool was an online questionnaire initially designed to gather information from opinion leaders, i.e. from businesses, higher education lecturers and professors. They can be considered experts with an excellent overall understanding of both the economic developments of their countries and general trends worldwide. Professional organizations and universities in India, Hungary, Finland and Croatia were contacted. These associations (Association Marketing Educators in Hungary, Croatian Marketing Association, and the Global Group of MBA Educators in India) agreed to distribute the questionnaire among their members who could involve their graduate students and business contacts using the snowball method. 
Three hundred fifteen questionnaires were received all together, and educators filled 157 of them. Due to the low number of responses from Finland, LinkedIn was used for further distribution of the questionnaire. By the end of the period, responses were received not only from Finland but from a dozen of other advanced or developed countries as well. Therefore, the research had a homogenous set of questionnaires from Croatia and Hungary representing transition countries and India representing emerging BRIC countries, and a heterogeneous set was received from advanced countries. The number of processed questionnaires was as follows (Table 1):

Table 1. The number of educators' responses

\begin{tabular}{lc}
\hline \multicolumn{1}{c}{ Country } & Number of responding educators \\
\hline Advanced countries & 19 \\
Croatia & 27 \\
Hungary & 46 \\
India & 65 \\
\hline Total number of educators & 157 \\
Total number of respondents & 315 \\
The share of educators & $50 \%$ \\
\hline
\end{tabular}

Source: Own data

\section{Research Results}

The description of the results of the primary research follows the logic of the questionnaire. Before going into details of the experts' evaluation of the megatrends' effect on marketing environment and communication, the study intended to learn about the respondents' opinion on specific important general issues regarding the development of marketing in the future. The next part of the research discussed results gained from the views about the possible effects of the global megatrends. The description of the findings was concluded with the analysis of changes expected in the future of marketing and their relevance from the aspect of higher education.

\section{The respondents' opinion on the general issues of marketing communications}

The first aim of our survey questionnaire was to find out what respondents think about the intensity of changes regarding the content and means used in marketing communications in the next decade. Respondents could select one of four statements: 1 . radical changes, 2. gradual changes, 3. minimal changes, and 4. no changes expected. As the number of answers including minimal or no change was rather low, the numbers for these two answers could be added up, allowing the use of only three categories. 
Figure 3 shows that there was no significant difference between the evaluation of business educators and non-educators. However, it is also visible that educators who were supposed to know not only the practice of business but also the predictions of the related scientific literature were somewhat more radical in their evaluations.

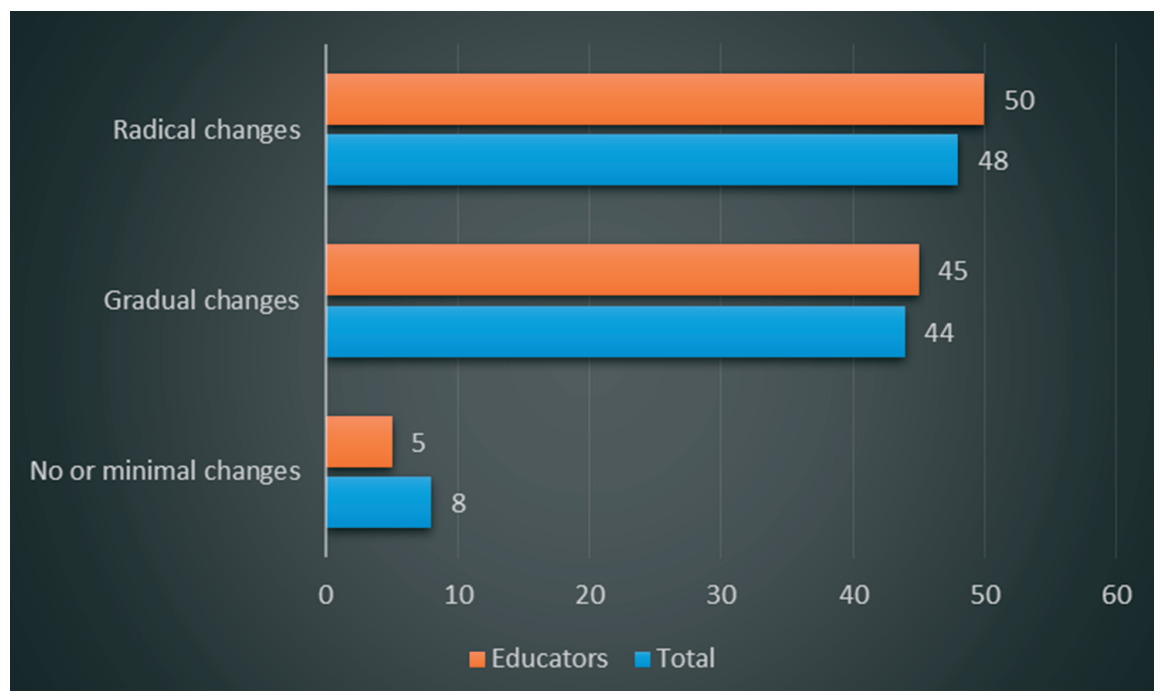

Figure 3. The evaluation of the expected intensity of changes among educators and the total sample (expressed in \%)

Source: Own data

The distribution of answers according to the variables (age, occupation, gender) showed no significant differences for the overall sample according to the Pearson Chi-Square Test. However, though, we could experience a considerable difference in the case of one variable. This difference appeared in the distribution of responses according to countries. The results are illustrated in Figure 4.

It is worthwhile to mention that almost two-thirds of Indian respondents think that radical changes will occur in the marketing communications of the next decade. This attitude correlates very much with the current good state of the economy in India, and most probably they assume that this status is likely to remain throughout the next ten years. Respondents from Hungary have rather moderate expectations, which is also thought-provoking. Almost one-sixth of Hungarian educators think that no changes or only minimal changes are expected in the field of communication.

The most important findings of the survey concerning the general issues of marketing communications in which all the respondents from the different countries agreed were: 1 . The marketing communications of small and medium-sized companies will not be as effective as that of larger ones. 2. Integrated marketing commu- 


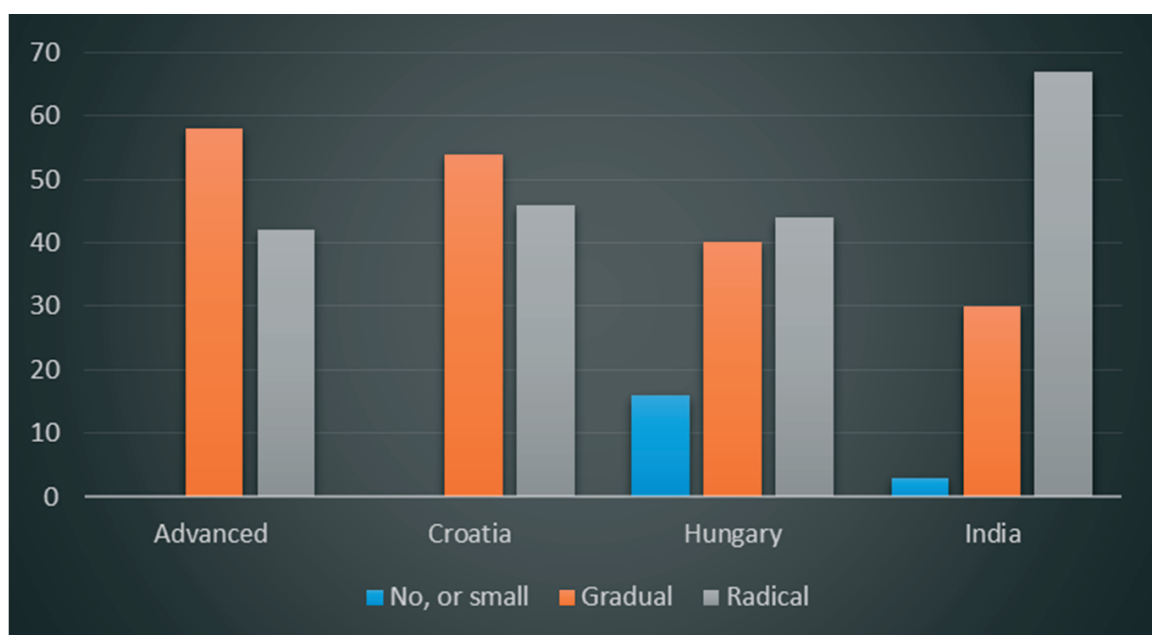

Figure 4. The pattern of feedback regarding the intensity of changes by countries (Educators, \%) $n=157$

Source: Own data

nication is becoming more important. 3. Online media expenditures will increase radically as compared with traditional media expenditures (Table 2).

Table 2. General issues of marketing communication where opinions were similar (educators \%)

\begin{tabular}{lrccccc}
\hline \multicolumn{1}{c}{ Statements } & Categories & $\begin{array}{c}\text { Advanced } \\
\text { countries }\end{array}$ & Croatia & Hungary & India \\
\hline The marketing communications of large & Agree & 37 & 30 & 37 & 55 \\
and small companies are becoming similar & Not agree & 63 & 70 & 63 & 45 \\
\hline Integral marketing communication & Agree & 85 & 89 & 93 & 86 \\
is becoming more important & Not agree & 15 & 11 & 7 & 14 \\
\hline \multirow{2}{*}{ Online media expenditure is increasing } & Agree & 95 & 89 & 94 & 67 \\
& Not agree & 5 & 11 & 6 & 33 \\
\hline
\end{tabular}

Source: Own data

Summarizing the above, we can formulate our next prediction as follows:

\section{Prediction no. 2}

The expected radical changes in the future also require radical changes in the education of marketing and marketing communication. Integrated marketing communication and online marketing must play a greater role in the education of marketing. 
The study found significant differences between the attitudes of Indians and other countries regarding in certain issues: 1 . Increase in total expenditure on marketing communication. 2. A decrease in expenditure on mass media. 3. Increasing share of governmental and non-profit organizations in marketing communication expenditures (Table 3 ).

Table 3. General issues of marketing communication with conflicting opinions (educators \%)

\begin{tabular}{|c|c|c|c|c|c|}
\hline Statements & Categories & $\begin{array}{l}\text { Advanced } \\
\text { countries }\end{array}$ & Croatia & Hungary & India \\
\hline \multirow{2}{*}{$\begin{array}{l}\text { Marketing communication expenditures } \\
\text { will increase significantly in your country }\end{array}$} & Agree & 26 & 48 & 33 & 85 \\
\hline & Not agree & 74 & 52 & 67 & 15 \\
\hline \multirow{2}{*}{$\begin{array}{l}\text { The ratio of mass media expenditures will be } \\
\text { higher in the marketing communication mix }\end{array}$} & Agree & 89 & 74 & 64 & 48 \\
\hline & Not agree & 11 & 26 & 36 & 52 \\
\hline \multirow{2}{*}{$\begin{array}{l}\text { The share of the expenditures of governmental } \\
\text { and non-profit organizations in total spending } \\
\text { will increase }\end{array}$} & Agree & 56 & 59 & 36 & 71 \\
\hline & Not agree & 44 & 41 & 63 & 29 \\
\hline
\end{tabular}

Source: Own data

To conclude, we can say that professionals from India showed a rather radical and - from their standpoint - more optimistic view as compared to other countries. This probably originates from their faith in their strong economy, and the opinion that it will also continue to be strong in the upcoming ten years.

\section{The issue of globalization or localization}

The scope of the research is international, and in such context the main question of marketing is whether to globalize or localize. Marketing communication is perhaps the most sensitive marketing tool in this sense. The reason why the issue is sensitive is that various customers live in various environments: they may speak different languages, have different religions and quite different sociocultural attitudes, etc. Marketing communication is the first contact point with customers, and it is of utmost importance that the customers should be able to decode the messages and understand the information. In order to send appropriate and clear messages, intercultural dialogue is needed. Intercultural dialogue largely depends on intercultural competencies. Defined as the 'complex of abilities needed to perform effectively and appropriately when interacting with those who are linguistically and culturally different from oneself' (Fantini, 2007), these abilities are essentially communicative. Still, they may also involve the reconfiguration of our perspectives and understanding the world (Unesco, 2009).

The question which is still there for business and non-business entities is whether to standardize the communication mix to achieve cost advantages or adapt to local conditions. The respondents from the four distinct areas mentioned above 
were asked about the globalization vs localization issue on a five-point Likert scale. The statement in question was "Due to cultural differences, marketing communication will mostly stay localized". Adding the "partially agree" and the "completely agree" categories together under the term Agree and comparing them to the sum of "strongly disagree", "partially disagree" and "neutral" answers with the title Not agree, we could see the following result (Figure 5)

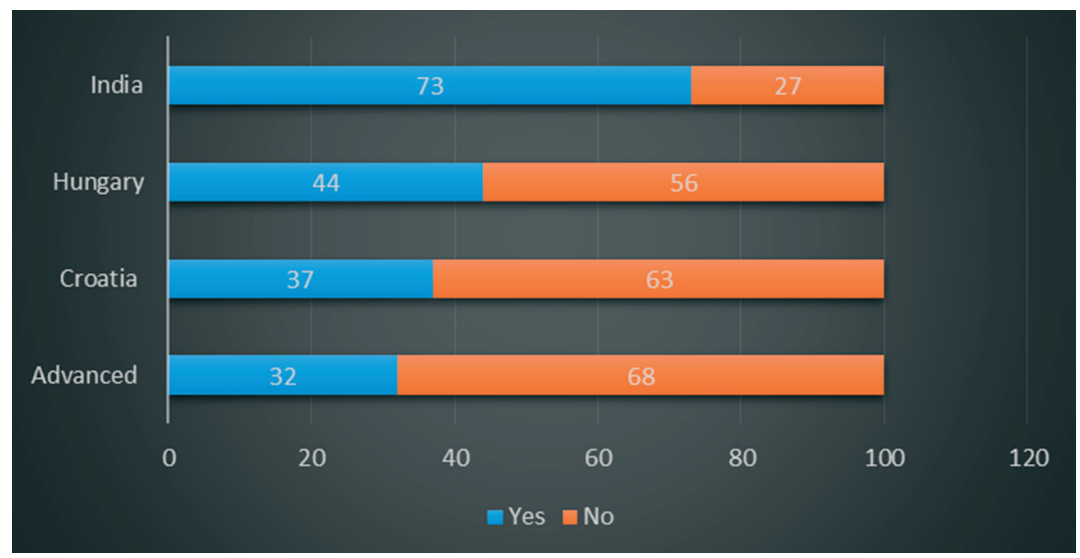

Figure 5. The difference of opinions on localization (Educators \%) $n=157$

Source: Own data

While the balance ratio of "Agree" and "Not agree" is around $50-50 \%$ in the case of Hungary and the examined advanced countries, Croatian respondents voted in favor of globalizing, while Indian respondents voted for localization. Their attitude is quite understandable: the growing Indian consumer market is somewhat fragmented. India's cultural diversity, its multilingualism, preferences and customs would probably make it difficult for companies to operate following a strategy of globalized marketing communications (Kurl, 2015; Kumar, 2009).

This question will be even more critical in the future, when - according to the forecast of an economic power shift - huge new export-markets will appear in emerging countries, especially in India and China. Companies striving to gain share on these new markets will immediately be faced with this issue. Rekettye (2016) gives a comprehensive and detailed analysis of the effects and consequences of the power shift in international marketing.

\section{Prediction no. 3}

The radical growth rate of emerging countries in international trade and the economic power shift require that universities pay much more attention to the cultural aspects of the business education and educate business graduates to be more sensitive culturally. 


\section{The significance of findings on the education}

\section{of marketing and marketing communications at the university level}

Higher education, in general, has had its dilemmas over the last decades, some of which are still powerful trends today. Globalization and internationalization are just two of the most critical trends affecting higher education on a global scale (Brock-Utne, 2002). The trends discussed in this study directly result in the changes that are taking place in higher education. Demographic trends have a significant impact on higher education, and many universities counteract it by the so-called internationalization process. According to Connick (1997) the changes that are taking place in higher education are mostly linked to the advance of technology. Information technology and telecommunications have modernized all facets of life. Students now have a powerful means of comparing educational institutions before they choose the best value and location according to their needs. This is most certainly powered by the rapid development of communication technology, which allows institutions to compete for prospective students on social media. Technology has also enabled institutions to offer new ways of teaching and learning. For example, distance education has become a well-adopted strategy for many institutions to offer their portfolio to an even larger group of customers, which is important as a result of current demographic changes.

Most of the surveyed educators agreed that there would be radical changes in marketing communications in the near future. This means that higher education institutions can only be pioneers if they adapt their curricula to the trends mentioned above. This not only means that their institutional communication needs to change, but the content of teaching marketing communications also needs to be updated in line with current trends. These, of course, include current online and offline practices. Still, more importantly, the methodology of transferring this knowledge to students must consist of a new mentality reflecting the digital age that we live in. Lukovics and Zuti (2017) discuss the evolution of universities in this dynamically changing environment, concluding that a new type of university, a so-called "fourth generation university" is surfacing. These institutions need to play a new role in the future, whose success will largely depend on the criteria of internationalism/mobility. Furthermore, the use of digital solutions in order to attract the new generation of students will also be emphasized according to experts.

The results of the research found many similarities among the surveyed countries. These areas reflect that the same principles apply to universities in their competition for the students and the ways they teach marketing communications. Cooperating with business actors is not a new idea, but one that may become even more necessary to understand the current trends in marketing. 


\section{Conclusion}

The present work focused on providing a better understanding of the megatrends influencing business practices with the help of international research. The sample of the research enabled us to explore the opinion of educators of higher education institutions and their views on how the changes will affect the future of marketing communications. The authors then used these findings to formulate three predictions based on secondary and primary research data. Firstly, the advance of digital technology embedded into business education needs to be more emphasized in the future. Secondly, the integrated approach of marketing communications and online practices need to be included in the curricula of teaching. Finally, as a result of the changes affecting higher education (namely, internationalization and the mobility of students) along with the other factors mentioned, cultural sensitivity will be crucial to the success of future graduates.

Further research may be carried out by widening the scope of the research, using a more precisely selected sample, further investigating the most important factors influencing the role of higher education in the future. The perspectives of marketing students and companies could also be integrated into a future research.

\section{References}

1. Baur, C., \& Wee, D. (2015). Manufacturing's next act. McKinsey \& Company. Retrieved on June 24, 2020 from https://www.mckinsey.com/business-functions/operations/ourinsights/manufacturings-next-act.

2. Brock-Utne, B. (2002). The Global Forces Affecting the Education Sector Today - The Universities in Europe as an Example. Higher Education in Europe, XXVII(3), Carfax Publishing. Retrieved on May 2, 2020 from https://doi.org/10.1080/0379772022000015023.

3. Connick. G. P. (1997). Issues and Trends to Take Us into the Twenty-First Century. New Directions for Teaching and Learning, 71, Jossey-Bass Publishers.

4. Dobbs, R., Manyika. J., \& Woetzel. J. (2015). No ordinary disruption. The Four Global Forces Breaking All the Trends. New York: Public Affairs.

5. Egan, J (2015). Marketing Communications. Sage Publications.

6. Fantini, A. (2007). Exploring Intercultural Competence: Developing, Measuring, and Monitoring. Research Report 07-01. St. Louis. Center for Social Development. Washington University. Retrieved on May 2, 2020 from http://csd.wustl.edu/Publications/Docume nts/RP07-01.pdf and http://proposals.nafsa.org/ Abstract_Uploads/118.61212.GS049.pdf.

7. Geissbauer, R., Vedsø, J. \& Schrauf, S. (2016). A Strategist's Guide to Industry 4.0. Strategy + Business, 83 .

8. Gregosz, D. (2012). Economic Megatrends up to 2020. Berlin: Konrad Adenauer Stiftung.

9. Kotler, P., Kartajaya, H. \& Setiawan. I. (2010). Marketing 3.0. Hoboken, NJ: Wiley.

10. Kumar, S. R. (2009). Adapting IMC to Emerging Markets: Importance of Cultural Values in the Indian Context. fournal of Integrated Marketing Communications, 38-42. Re- 
trieved on June 24, 2020 from http://jimc.medill.northwestern.edu/wp-content/uploads/ sites/9/2014/02/archives/2009/IMC_to_Emerging_Markets.pdf.

11. Kurl, D. (2015). Understanding Integrated Marketing Communication in India. Retrieved on June 24, 2020 from http://www.exchange4media.com/viewpoint/viewpoint. asp?view_id=95.

12. Larsen, G. (2006). Why megatrends matter. Copenhagen Institute for Future Studies.

13. Lukovics, M. \& Zuti, B. (2017). New Functions of Universities in Century XXI Towards "Fourth Generation" Universities (academia.edu 9: Paper ID: 20371078. San Francisco, California). Retrieved on May 4, 2020 from https://ssrn.com/abstract=3022727.

14. Monostori, L. (2015). Cyber-physical production systems: roots from manufacturing science and technology. Automatisierungstechnik, 63(10), 766-776. http://dx.doi. org/10.1515/auto-2015-0066.

15. NIC (National Intelligence Council) (2008). Global Trends 2025: A Transformed World. Washington, DC.

16. Quelch, J.A., \& Jocz, K.E. (2009). How to market in downturn. Harvard Business Review. Reprint R0904D. Retrieved on May 4, 2020 from https://hbr.org/2009/04/how-to-marketin-a-downturn-2.

17. Papp-Váry, Á. (2013). A márkanév ereje (The strength of branding). Dialóg Campus Kiadó Budapest-Pécs.

18. Porter, M.E. \& Heppelmann, J.E. (2014). How Smart, Connected Products Are Transforming Competition. Harvard Business Review. Retrieved on May 4, 2020 from https:// hbr.org/2014/11/how-smart-connected-products-are-transforming-competition.

19. Rekettye, G. (2016). A hatalmi átalakulás globális megatrendje és a nemzetközi marketing [The megatrend of the power-shift and the international marketing]. Budapest Management Review, 47(4).

20. Rekettye, G., \& Rekettye, G. Jr. (2013). Global trends and their influence on future business performance. International Journal of Business Performance Management. 14(1), 95-110. http://dx.doi.org/10.1504/IJBPM.2013.050589.

21. Rüßman, M., Lorenz, M., Gerbert, P., Waldner, M., Justus, J., Engel, P., \& Harnisch, M. (2015). Industry 4.0, Boston Consulting Group. Retrieved on May 15, 2020 from https:// www.zvw.de/media.media.72e472fb-1698-4a15-8858-344351c8902f.original.pdf.

22. Schwab, K. (2016). The Fourth Industrial Revolution: What It Means, How to Respond, World Economic Forum. Retrieved on May 15, 2020 from https://www.weforum.org/ agenda/2016/01/the-fourth-industrial-revolution-what-it-means-and-how-to-respond/.

23. Strange, R. \& Zuchella A. (2017). Industry 4.0, global value chains and international business. Multinational Business Review, 25(3), 174-184. http://dx.doi.org/10.1108/MBR-052017-0028.

24. Tao, F., Cheng, Y., Zhang, L., \& Nee, A.Y.C. (2015). Advanced manufacturing systems: socialization characteristics and trends. Journal of Intelligent Manufacturing, 18. http:// dx.doi.org/10.1007/s10845-015-1042-8.

25. Unesco World Report (2009). Investing in Cultural Diversity and Intercultural Dialogue. Paris: United Nations Educational. Cultural and Scientific Organization. Retrieved on 
May 20, 2020, from http://www.un.org/en/events/culturaldiversityday/pdf/Investing in_cultural_diversity.pdf.

26. Vielmetter, G. \& Sell, Y. (2014). Leadership 2030: The Six Megatrends You Need to Understand to Lead your Company into the Future. New York: Hay Group Holding.

27. Vijay, C. (2009). Marketing Strategy for the 21st Century. fournal of Marketing \& Communication, 5(1), 88-91.

28. Wine, R. S. (2009). New Communications Approaches in Marketing: Issues and Research Directions. Journal of Interactive Marketing, 23(2), 108-117. 